\title{
Progress of Non-Aqueous Electrolyte for Li-Air Batteries
}

\author{
Xianjun Liu, Baochen Cui, Shuzhi Liu, Yun Chen \\ Chemistry and Chemical Engineering School of Northeast Petroleum University, Daqing, China \\ Email: Ixjlj2000@126.com
}

Received 16 February 2015; accepted 21 April 2015; published 24 April 2015

Copyright (C) 2015 by authors and Scientific Research Publishing Inc.

This work is licensed under the Creative Commons Attribution International License (CC BY). http://creativecommons.org/licenses/by/4.0/

c) (i) Open Access

\begin{abstract}
Li-air batteries have received much attention in the past several years because of their large theoretical specific energy density, stable output voltage, cost-effective, energy-efficient and pollution free, and have broad application prospects. If it is successfully developed, the battery could be an excellent energy storage device for renewable energy sources such as wind, solar, and tidal energy, which brings a prospect for human to solve the problem of environment pollution and energy crisis. But the electrolyte is a crucial component of Li-air battery and the electrochemical performance of the battery is determined by electrolyte to a great extent. Due to the react violently between lithium and water, it is not practical for Li-air battery to use directly an aqueous electrolyte unless the anode can be protected from degradation. In this review, we presented the latest research progress on the non-aqueous electrolyte, i.e. organic electrolyte, ionic liquid and solid electrolyte. We elaborated the influence of solvents, and possible additives, and/or their combination Li-air battery's performance. Finally, we provided insights into the prospect of non-aqueous electrolyte for Li-air battery.
\end{abstract}

\section{Keywords}

Li-Air Battery, Organic Electrolyte, Ionic Liquid, Solid Electrolyte, Research Progress

\section{Introduction}

Energy and the environment are among the most important issues of the twenty-first century. Until now the main energy supply comes from fossil fuels, such as coal, oil, and natural gas, causing a dramatic build-up of greenhouse gases in the atmosphere. In response, energy conversion from renewable sources has been considered as a promising solution to decrease $\mathrm{CO}_{2}$ emissions that has paved the way for governmental incentives toward both the implementation of electric vehicles and hybrid electric vehicles. However, rechargeable energy storage systems with high energy density and round-trip efficiency are urgently needed to capture and deliver 
renewable energy for applications such as electric transportation. Metal-air batteries have received extraordinary research attention recently as promising electrochemical energy storage and conversion devices due to their extremely high energy density, low cost, and environmentally friendly operation [1] [2]. Many researchers have worked to develop rechargeable metal-air batteries as next-generation batteries in recent years. Typically, metal-air batteries are divided into two types according to the electrolyte: one is a cell system using an aqueous electrolyte such as Zn-air and the other is a water-sensitive system using organic electrolyte such as nonaqueous Li-air [3] [4]. In the non-aqueous system it has been proved that the reduction products can be reversed into the original reagents and is advantageous for the rechargeability. Moreover, the theoretical energy density of a non-aqueous Li-air battery system is higher than that of an aqueous Li-air battery system because of the water or acid being involved in the reactions in the aqueous system. To date, the non-aqueous configuration has attracted the most effort worldwide compared to other electrolyte systems in Li-air batteries. Due to the nonaqueous reaction mechanism and the lightest metal element of lithium, its theoretical energy density is approximately $11680 \mathrm{~W} \cdot \mathrm{h} \cdot \mathrm{kg}^{-1}$ [5]. This special and fascinating energy storage system attracts a lot of technological and scientific interest.

The working principle of a rechargeable Li-air battery is shown in Figure 1. The discharge reaction in an Li-air battery is the reduction of $\mathrm{O}_{2}$ with lithium ions to form lithium (per) oxide. During charge, these oxides are decomposed electrochemically to regenerate lithium and $\mathrm{O}_{2}$. Under the assumption of complete filling of pore space in highly porous electrodes having $60 \%$ void volume, the formation of $\mathrm{Li}_{2} \mathrm{O}_{2}$ and $\mathrm{Li}_{2} \mathrm{O}$ in the $\mathrm{O}_{2}$ electrode can potentially provide $900 \mathrm{~mA} \cdot \mathrm{h} \cdot \mathrm{gelectrode}^{-1}$ and $1350 \mathrm{~mA} \cdot \mathrm{h} \cdot \mathrm{gelectrode}^{-1}$ (normalized to the mass of the $\mathrm{O}_{2}$ electrode in the discharged state) [6] [7], respectively. These values are significantly higher than those ( 200 $\mathrm{mA} \cdot \mathrm{h} \cdot \mathrm{g}_{\text {electrode }}{ }^{-1}$ ) of conventional intercalation compounds used in the positive electrode of Li-ion batteries [6][8].

Though Li-air batteries have a relative high voltage and energy density, there are a number of challenges including poor round-trip efficiency [9]-[11], poor rate capability [5] [12] [13], low cycle life [14] [15] and poor safety characteristic to limit the practical application of the Li-air batteries, as shown in Figure 2. Several of these challenges are common to all lithium batteries, and if they could be solved, it would equally improve Li-ion batteries as well.

A major challenge to moving ahead even at the research level is to find a stable electrolyte for the nonaqueous Li-air batteries. The electrolyte in the non-aqueous Li-air battery has a profound influence on the reactions that occur at the anode and cathode, and hence its overall operation on discharge/charge. Non-aqueous electrolytes have been studied and developed for decades and successfully employed in the present commercialized Li-ion batteries. But they must possess a wide range of attributes, exceeding the requirements of electrolytes for Li-ion batteries by far. This makes Li-air batteries more challenging and generates the brand new subject of non-aqueous electrolytes for Li-air batteries. Choosing a suitable electrolyte is crucial to the performance of Li-air batteries. The non-aqueous electrolytes for Li-air batteries in this perspective are exclusively focused on organic electrolytes, ionic liquids and solid-state electrolytes.

\section{Organic Electrolytes}

An ideal electrolyte for non-aqueous Li-air batteries should hold high chemical and electrochemical stability, low volatility or no volatility to guarantee long-term operation, high oxygen solubility, and especially, be inert to superoxide radicals. However, none of the reported electrolytes can completely meet these requirements.

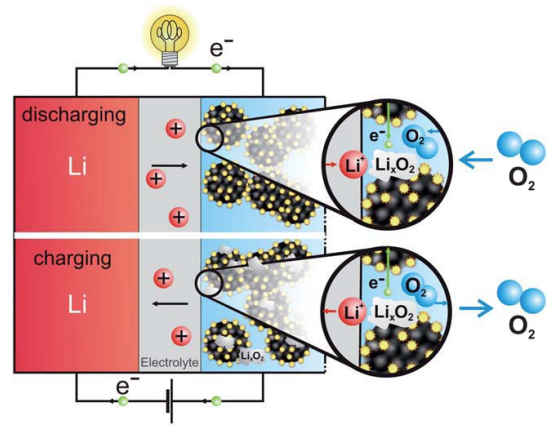

Figure 1. Working principle of a rechargeable Li-air battery [6]. 


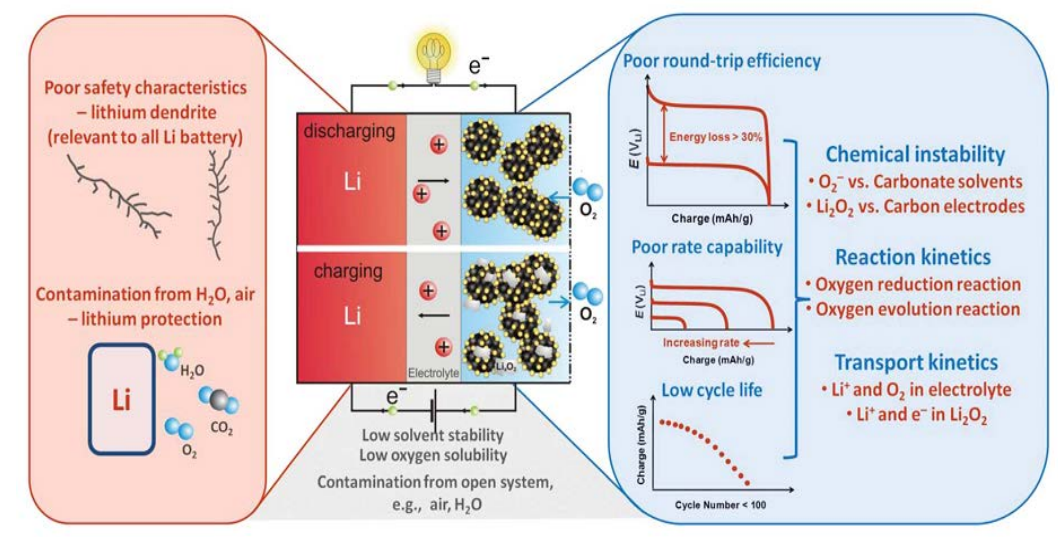

Figure 2. Major challenges of rechargeable Li-air batteries [16].

Organic electrolyte is mainly composed of high purity of organic solvent and electrolyte of lithium salt according to certain proportion. The properties of formulated electrolytes are crucial to the interfacial structure between electrodes, $\mathrm{O}_{2}$ gas, and non-aqueous electrolytes and accordingly govern the performance of Li-air batteries. The effect is the result of the individual components of the electrolytes: organic solvents, Li salts, and possible additives, and/or their combination.

\subsection{Organic Solvents}

One of the problems with non-aqueous Li-air batteries is the attack on solvent molecules by oxygen radicals [17]-[19]. All the publications involving non-aqueous electrolytes for Li-air batteries have focused on searching for a solvent that is stable against oxygen radicals. An electrolyte solvent for Li-air batteries is expected to have the following merits [20]: 1) a high dielectric constant, able to dissolve a certain amount of Li salt; 2) low viscosity, supporting fast $\mathrm{Li}^{+}$ion transport in cells; 3) high stability against all cell components, especially oxygen radicals during cell operation; 4) low vapour pressure, limited loss when exposed to an $\mathrm{O}_{2}$ flow; and 5) nontoxicity and economic use. Organic solvents such as propylene carbonate (PC), acetonitrile (AcN), dimethyl sulfoxide (DMSO), glymes, etc., have been widely used in Li-air batteries.

Organic carbonates. Ethylene carbonate (EC) and propylene carbonate (PC) are commonly used as solvent for Li-air batteries in the early stages due to their high boiling point and considerable ion conductivity. They were the first applied as non-aqueous electrolyte solvents in Li-air batteries in 2006, In the following few years, organic carbonates were almost the benchmark electrolyte solvents in Li-air batteries and subsequently, different research areas involving Li-air batteries were developed.

However, in 2010, Mizuno et al. [16] reported that carbonate solvents could be attacked by oxygen radicals which were generated during discharge. This led to formation of lithium carbonate $\left(\mathrm{Li}_{2} \mathrm{CO}_{3}\right)$ and other lithium alkyl carbonates $(\mathrm{RO}-(\mathrm{C}=\mathrm{O})-\mathrm{OLi})$, instead of the previously claimed discharge product $\mathrm{Li}_{2} \mathrm{O}_{2}$. $\mathrm{Later}$ Bruce's group further confirmed this result and reported that an alkyl carbonate electrolyte decomposed into $\mathrm{C}_{3} \mathrm{H}_{6}\left(\mathrm{OCO}_{2} \mathrm{Li}\right)_{2}, \mathrm{Li}_{2} \mathrm{CO}_{3}, \mathrm{HCO}_{2} \mathrm{Li}, \mathrm{CH}_{3} \mathrm{CO}_{2} \mathrm{Li}, \mathrm{CO}_{2}$, and $\mathrm{H}_{2} \mathrm{O}$ at the cathode during discharge and charging involved the oxidation of $\mathrm{C}_{3} \mathrm{H}_{6}\left(\mathrm{OCO}_{2} \mathrm{Li}\right)_{2}, \mathrm{Li}_{2} \mathrm{CO}_{3}, \mathrm{HCO}_{2} \mathrm{Li}, \mathrm{CH}_{3} \mathrm{CO}_{2} \mathrm{Li}$ accompanied by $\mathrm{CO}_{2}$ and $\mathrm{H}_{2} \mathrm{O}$ evolution [18]. A similar observation of the decomposition of organic carbonates was also obtained by other groups [21]-[23]. It seriously affected the reversibility of the Li-air battery.

Ethers. Ether solvents came into consideration for electrolyte solvents for Li-air batteries after organic carbonates were found to suffer severe decomposition. Since then, ether solvents have been investigated experimentally. Ether solvents were found to have relatively higher stabilities than PC. $\mathrm{Li}_{2} \mathrm{O}_{2}$ could be observed as the main discharge product in dimethoxyethane (DME) based Li-air cells by McCloskey [24]. But with the deepening of the research, it was found that ethers electrolyte solvents are unstable. The results from Bruce and coworkers showed that the amount of $\mathrm{Li}_{2} \mathrm{O}_{2}$ in the discharge products gradually decreased during cycling for the ether electrolyte and at the fifth discharge, no $\mathrm{Li}_{2} \mathrm{O}_{2}$ was observed but other lithium compounds were observed in the discharge products [25]. Furthermore, the electrolyte degradation appeared to increase rapidly with cycling. The degradation mechanism of ethers in the presence of $\mathrm{O}_{2}$ has been attributed to the autoxidation of ethers by $\mathrm{O}_{2}$ [26]. It is suggested that the resistance to autoxidation can be improved by substitution of reactive hydro- 
gens on solvent molecules, for example by introducing steric hindrance at the reaction center [26]. In addition, ester based electrolytes are often plagued by the high volatility or high viscosity, which is a disadvantage to cycle life and rate performance of Li-air batteries. Such as DME and tetrahydrofuran (THF), is the low vapour pressure. It enables the fast evaporation of ether solvents in a few days and accordingly induces the decaying cycling performance. Although DME is more resistant to $\mathrm{O}_{2}$ radicals than organic carbonates, its low vapour pressure will restrict its wide application in Li-air batteries due to issues with long-term operation.

Sulfones. Dimethyl sulfoxide (DMSO), as a universal solvent, possesses favourable advantageous, including low volatility and viscosity, good oxygen difiusion ability, high conductivity containing $\mathrm{Li}^{+}$salts, and especially, remarkable stability against superoxides [27]. Thereafter, it is highly desirable to investigate the electrochemical behaviours of DMSO in $\mathrm{Li}^{+}$containing environments and further evaluate its performance in Li-air batteries. Xu et al. [28] first employed DMSO as an electrolyte solvent with $0.8 \mathrm{mg}$ of carbon in $\mathrm{Ni}$ foam as a cathode and evaluate its performance in Li-air batteries. It presented a large specific capacity based on the unit mass of carbon and a high discharge voltage. Because DMSO can react with Li metal, Li foils were pre-treated in $1 \mathrm{M}$ $\mathrm{LiClO}_{4}$ in PC to permit cycling. With the treated Li foil, DMSO, and a nanoporous gold foil (NPG) as the cathode, a reversible and higher-rate Li-air battery was built [29]. The discharge/charge capacity of the Li-air battery realized over 100 cycles with little decay. Unfortunately, such an electrolyte is only efficient on a gold electrode and if carbon materials exist, the decomposition reactions are also serious.

Other solvents. Other classes of electrolytes including silane-based and amide-based solvents with various substitutions have been valuated experimentally and theoretically as alternatives for Li-air batteries. Zhang and co-workers [30] have reported that oligoether-functionalized silane solvent exhibits improved ability compared to PC. However, there existed some electrolyte decomposition during discharge. The search for a stable cycling and low vapour pressure solvent is urgent for a long-term stable Li-air battery.

\subsection{Lithium Salts}

As an indispensable component of electrolytes, Li salts must meet the prerequisites before being used in Li-air batteries [31]: 1) Li salts should be able to dissolve in solvents and reach a certain concentration to support fast $\mathrm{Li}^{+}$ion transport; 2) anions must be stable under the required potentials; 3) anions should be inert to the solvent, and 4) anions should be stable against the cell components, such as the current collectors, separators, and the package. $\mathrm{Li}$ salts such as $\mathrm{LiPF}_{6}, \mathrm{LiClO}_{4}, \mathrm{LiCF}_{3} \mathrm{SO}_{3}, \mathrm{LiN}\left(\mathrm{SO}_{2} \mathrm{CF}_{3}\right)_{2}, \mathrm{LiN}\left(\mathrm{SO}_{2} \mathrm{C}_{2} \mathrm{~F}_{5}\right)_{2}, \mathrm{Li} \mathrm{Br}$, Li I, etc., have been widely used in Li-air batteries. Because of their limited availability, Li salts have not attracted much attention, compared with the interest in selecting solvents for the electrolytes of Li-air batteries.

Several recent studies [32]-[34] have shown that lithium salts can react with $\mathrm{Li}_{2} \mathrm{O}_{2}$ during discharge. Upon investigation of the discharge product in tetraglyme with various salts by XPS, Veith and co-workers [33] have detected contamination of $\mathrm{Li}_{2} \mathrm{O}_{2}$ by decomposed halide species from the electrolyte anions in $\mathrm{LiClO}_{4}, \mathrm{LiBF}_{4}$, $\mathrm{LiPF}_{6}$ and LiTFSI on the surface of $\mathrm{Li}_{2} \mathrm{O}_{2}$. Additionally, a recent study by $\mathrm{Xu}$ et al. [34] observed the presence of $\mathrm{LiF}$ in discharged electrodes with LiTFSI and a wide range of organic solvents, which was attributed to salt and/or binder (PTFE) decomposition.

In the electrolyte, the lithium salts concentration is also an influencing factor for battery performance [35]. The varying of the molar ratios of lithium salt and solvent can modify their solvate structures from solvent separated ion pairs to contact ion pairs [34]. The dependence of the cycling performance of the Li-air batteries on the concentrations will be helpful for exploiting the stable electrolyte systems [36].

\subsection{Additives}

Additives are the compounds which are in electrolytes with limited amounts but can greatly improve the performance of Li-air batteries. The functions of additives can be described as improving the dissolution of $\mathrm{Li}_{2} \mathrm{O}_{2}$ and $\mathrm{O}_{2}$ in electrolytes, both of which have the aim of increasing the discharge capacity. For the former, tris (pentafluorophenyl) borane (TPFPB) $\mathrm{B}\left(\mathrm{C}_{6} \mathrm{~F}_{5}\right)_{3}$ was added into carbonate based electrolytes to increase the dissolution of the discharge product $\mathrm{Li}_{2} \mathrm{O}_{2}$ and enable further oxygen reduction reaction to occur at the released active sites [37]. In order to increase the $\mathrm{O}_{2}$ solubility in propylene carbonate, perfluorotributylamine (FTBA) was added. The discharge capacity could be improved greatly compared to that with the electrolyte without FTBA [38] [39]. The idea of storing the discharge product $\mathrm{Li}_{2} \mathrm{O}_{2}$ in the electrolyte is promising for improving the specific capacity and avoiding the blockage of channels in the cathode, but the stability of this system needs careful evaluation. 


\section{Ionic Liquids Electrolytes}

Ionic liquids (ILs) offer several advantages as electrolytes for Li-air batteries including negligible vapor pressure and hydrophobicity. Their stabilities toward superoxide radical have been systematically investigated [16]. Mizuno et al. [40] have shown that N-methyl-N-propylpiperidinium bis (trifluoromethanesulfonyl) amide (PP13TFSA) is much more stable than carbonate-based solvents (against superoxide radical), owing to its less positive atomic charge compared to that of carbonate-type solvents. Recently, Herranz et al. [41] reported that 1-butyl-1methyl-pyrrolidinium bis (trifluoromethylsulfonyl) imide (Pyr14TFSI) exhibits at least three orders of magnitude enhanced stability (i.e., lower reaction rate constant with superoxide radical) compared to PC using rotating ring disk electrode technique. Although these ILs show promising stability toward the superoxide radical, their limited $\mathrm{O}_{2}$ solubility and diffusivity may lead to poor discharge capacity and rate capability of Li-air batteries.

\section{Solid-State Electrolytes}

Solid-state electrolyte possesses a wide electrochemical window and is relatively stable in comparison with the organic liquid electrolyte counterpart. Another advantage of the solid-state electrolyte membrane is the non-permeability of humidity and $\mathrm{CO}_{2}$, preventing the $\mathrm{Li}$ foil anode from reacting with $\mathrm{H}_{2} \mathrm{O}$ and $\mathrm{CO}_{2}$ in air.

Solid-state electrolytes have been pursued for decades and promise potential replacement of organic liquid electrolytes to improve the safety of Li-ion batteries. Increasing the electrochemical stability and conductivity of solid-state electrolytes for practical application in Li-ion batteries at room temperature is the main challenge. Selecting a suitable solid-state electrolyte is equally important as the cathode catalyst for construction of a porous air cathode and eventually affects the performance of the solid-state Li-air battery.

The currently employed electrolytes in solid-state Li-air batteries are ceramics, LAGP, and PEO polymer electrolytes, because of their availability and processability. Another important criterion for the employed solid-state electrolyte is its compatibility with superoxide radicals and Lioxide species $\mathrm{LiO}_{\mathrm{x}}$ [42]. The ceramic solid-state electrolyte usually consists of different components, such as $\mathrm{Li}_{2} \mathrm{O}$ and $\mathrm{BN}$, which may react with $\mathrm{H}_{2} \mathrm{O}$ and $\mathrm{CO}_{2}$ in air or be oxidized at high potentials. PEO is the most common material for the solid-state electrolytes and can be considered as one glyme with a very long molecular chain. The conductivity can be improved by an order of magnitude with the addition of inorganic nanoparticles, such as $\mathrm{TiO}_{2}$ and $\mathrm{Al}_{2} \mathrm{O}_{3}$ [43]. The enhancement was attributed to the local electric fields created by the nanoparticles interacting with $\mathrm{Li}^{+}$ions, which could accelerate the transport of the remaining conducting ions [43] [44]. Alternations on the polymer, composition, and inorganic nanoparticles have been exclusively attempted. LAGP has a composition of $\mathrm{Li}_{1+\mathrm{x}} \mathrm{Al}_{\mathrm{x}} \mathrm{Ge}_{2-\mathrm{x}}$ $\left(\mathrm{PO}_{4}\right)_{3}$, which is a derivative of $\mathrm{LiGe}_{2}\left(\mathrm{PO}_{4}\right)_{3}$. In addition to working as an electrolyte, LAGP is a major component of the cathode which has some ORR catalytic activity and forms $\mathrm{Li}^{+}$ion con ducting networks inside [42]. Unlike Li-air battery research in organic electrolytes, little information is available about reaction products in cells based on solid electrolytes used to date.

The major resistance of a solid-state Li-air battery is derived from the interfacial contacts, which govern the battery performance. The interfacial contacts include $\mathrm{Li} /$ solid-state electrolyte and solid-state electrolyte/cathode. Interfacial contacts governing the migration of $\mathrm{Li}^{+}$ions throughout a cell is crucially important for solid-state $\mathrm{Li}$ batteries. How to build good interfacial contacts among the Li/solid-state electrolyte and solid-state electrolyte/cathode is crucial for a rechargeable solid-state Li-air battery.

\section{Conclusions and Outlook for Non-Aqueous Electrolyte}

Much advance has been achieved, but the challenges remain. A major challenge to moving ahead even at the research level is to find a stable electrolyte for the non-aqueous Li-air batteries. On screening all the known electrolyte parasitic reactions have more or less been found. The electrolyte should be resistant to oxygen radicals during discharge and possible oxidation, especially in the presence of $\mathrm{Li}_{2} \mathrm{O}_{2}$ during charging. Li-air batteries with organic liquid electrolytes are facing great challenges, especially, the instability of organic electrolytes. On the other hand, the electrolyte cannot be studied without considering the effect of the cathode materials, because the cathode materials may catalyze the decomposition of the electrolyte under some potentials. Although ILs show promising stability toward the superoxide radical, their limited $\mathrm{O}_{2}$ solubility and diffusivity may limit their using in Li-air batteries. Solid-state electrolyte possesses a wide electrochemical window and is relatively stable in comparison with the organic liquid electrolyte counterpart. Another advantage of the solid-state electrolyte membrane is the non-permeability of humidity and $\mathrm{CO}_{2}$, preventing the Li foil anode from reacting with $\mathrm{H}_{2} \mathrm{O}$ 
and $\mathrm{CO}_{2}$ in air. Although the low ionic conductivity of solid-state electrolytes at room temperature represents a significant and continuing challenge to the development of solid state Li-air batteries, opportunities exist to increase the ionic conductivity of both polymer and ceramic electrolytes, while maintaining the stable, non-volatile properties of solid state electrolytes. Although great progress has been made in only a few years, future work on non-aqueous electrolytes for Li-air batteries will need to explore other electrolytes in the quest for yet lower cost, higher safety, stability and low volatility.

\section{Acknowledgements}

We are grateful to the National Natural Science Foundation of China (21473028) for support of this study.

\section{References}

[1] Armand, M. and Tarascon, J.-M. (2008) Building Better Batteries. Nature, 451, 652-657. http://dx.doi.org/10.1038/451652a

[2] Heng, F. and Chen, J. (2012) Metal-Air Batteries: From Oxygen Reduction Electrochemistry to Cathode Catalysts. Chemical Society Reviews, 41, 2172-2192. http://dx.doi.org/10.1039/c1cs15228a

[3] Lee, S., Kim, S.T., Cao, R., et al. (2011) Metal-Air Batteries with High Energy Density: Li-Air versus Zn-Air. Advanced Energy Materials, 1, 34-50.

[4] Abraham, K.M. and Jiang, Z. (1996) A Polymer Electrolyte-Based Rechargeable Lithium/Oxygen Battery. Journal of the Electrochemical Society, 143, 1-5. http://dx.doi.org/10.1149/1.1836378

[5] Girishkumar, G., McCloskey, B., Luntz, A., Swanson, S. and Wilcke, W. (2010) Lithium-Air Battery: Promise and Challenges. Journal of Physical Chemistry Letters, 1, 2193-2203. http://dx.doi.org/10.1021/jz1005384

[6] Lu, Y.-C., Kwabi, D.G., Yao, K.P.C., et al. (2011) The Discharge Rate Capability of Rechargeable Li-O ${ }_{2}$ Batteries. Energy \& Environmental Science, 4, 2999-3007. http://dx.doi.org/10.1039/c1ee01500a

[7] Lu, Y.-C., Gasteiger, H.A., Parent, M.C., Chiloyan, V. and Shao-Horn, Y. (2010) The Influence of Catalysts on Discharge and Charge Voltages of Rechargeable Li-Oxygen Batteries. Electrochemical and Solid-State Letters, 13, A69A72. http://dx.doi.org/10.1149/1.3363047

[8] Goodenough, J.B. and Kim, Y. (2009) Challenges for Rechargeable Li Batteries. Chemistry of Materials, 22, 587-603. http://dx.doi.org/10.1021/cm901452z

[9] Debart, A., Bao, J., Armstrong, G. and Bruce, P.G. (2010) An $\mathrm{O}_{2}$ Cathode for Rechargeable Lithium Batteries: The Effect of a Catalyst. Journal of Power Sources, 174, 1177-1182. http://dx.doi.org/10.1016/j.jpowsour.2007.06.180

[10] Debart, A., Paterson, A.J., Bao, J. and Bruce, P.G. (2008) Alpha- $\mathrm{MnO}_{2}$ Nanowires: A Catalyst for the O-2 Electrode in Rechargeable Lithium Batteries. Angew. Angewandte Chemie International Edition, 47, 4521-4524. http://dx.doi.org/10.1002/anie.200705648

[11] Lu, Y.-C., Xu, Z.C., Gasteiger, H.A., et al. (2010) Platinum-Gold Nanoparticles: A Highly Active Bifunctional Electrocatalyst for Rechargeable Lithium-Air Batteries. Journal of the American Chemical Society, 132, 12170-12171. http://dx.doi.org/10.1021/ja1036572

[12] Zhang, S.S., Foster, D. and Read, J. (2010) Discharge Characteristic of a Non-Aqueous Electrolyte Li/O2 Battery. Journal of Power Sources, 195, 1235-1240. http://dx.doi.org/10.1016/j.jpowsour.2009.08.088

[13] Zhang, G.Q., Zheng, J.P., Liang, R., et al. (2010) Lithium-Air Batteries Using SWNT/CNF Buckypapers as Air Electrodes. Journal of the Electrochemical Society, 2010, 157, A953-A956. http://dx.doi.org/10.1149/1.3446852

[14] Cheng, H. and Scott, K. (2010) Carbon-Supported Manganese Oxide Nanocatalysts for Rechargeable Lithium-Air Batteries. Journal of Power Sources, 195, 1370-1374. http://dx.doi.org/10.1016/j.jpowsour.2009.09.030

[15] Mizuno, F., Nakanishi, S., Kotani, Y., Yokoishi, S. and Iba, H. (2010) Rechargeable Li-Air Batteries with CarbonateBased Liquid Electrolytes. Electrochemistry, 78, 403-405. http://dx.doi.org/10.5796/electrochemistry.78.403

[16] Lu, Y.-C., Gallant, B.M., Kwabi, D.G., et al. (2013) Lithium-Oxygen Batteries: Bridging Mechanistic Understanding and Battery Performance. Energy \& Environmental Science, 6, 750-768. http://dx.doi.org/10.1039/c3ee23966g

[17] Freunberger, S.A., Chen, Y.H., Peng, Z.Q., Griffin, J.M., Hardwick, L.J., Bardé, F., et al. (2011) Reactions in the Rechargeable Lithium- $\mathrm{O}_{2}$ Battery with Alkyl Carbonate Electrolytes. Journal of the American Chemical Society, 133, 8040-8047. http://dx.doi.org/10.1021/ja2021747

[18] Trahan, M.J., Mukerjee, S., Plichta, E.J. Hendrickson M.A. and Abraham, K.M. (2013) Cobalt Phthalocyanine Catalyzed Lithium-Air Batteries. Journal of the Electrochemical Society, 160, A1577-A1586. 
http://dx.doi.org/10.1149/2.118309jes

[19] Chen, Y., Freunberger, S.A., Peng, Z., Bardé, F. and Bruce, P.G. (2012) Li-O 2 Battery with a Dimethylformamide Electrolyte. Journal of the American Chemical Society, 134, 7952-7957. http://dx.doi.org/10.1021/ja302178w

[20] Xu, K. (2004) Nonaqueous Liquid Electrolytes for Lithium-Based Rechargeable Batteries. Chemical Reviews, 104, 43034418. http://dx.doi.org/10.1021/cr030203g

[21] Xu, W., Xu, K., Viswanathan, V.V., Towne, S.A., Hardy, J.S., Xiao, J., et al. (2011) Reaction Mechanisms for the Limited Reversibility of Li-O $\mathrm{O}_{2}$ Chemistry in Organic Carbonate Electrolytes. Journal of Power Sources, 196, 96319639. http://dx.doi.org/10.1016/j.jpowsour.2011.06.099

[22] Xiao, J., Hu, J., Wang, D., Hu, D.H., Xu, W., Graff, G.L., et al. (2011) Investigation of the Rechargeability of Li-O ${ }_{2}$ Batteries in Non-Aqueous Electrolyte. Journal of Power Sources, 196, 5674-5678. http://dx.doi.org/10.1016/j.jpowsour.2011.02.060

[23] Veith, G.M., Dudney, N.J., Howe, J. and Nanda, J. (2011) Spectroscopic Characterization of Solid Discharge Products in Li-Air Cells with Aprotic Carbonate Electrolytes. Journal of Physical Chemistry C, 115, 14325-14333.

[24] McCloskey, B.D., Bethune, D.S., Shelby, R.M., Girishkumar, G. and Luntz, A.C. (2011) Solvents' Critical Role in Nonaqueous Lithium-Oxygen Battery Electrochemistry. Journal of Physical Chemistry Letters, 2, 1161-1166. http://dx.doi.org/10.1021/jz200352v

[25] Freunberger, S.A., Chen, Y., Drewett, N.E., Hardwick, L.J., Bardé, F. and Bruce, P.G. (2011) The Lithium-Oxygen Battery with Ether-Based Electrolytes. Angewandte Chemie International Edition, 50, 8609-8613. http://dx.doi.org/10.1002/anie.201102357

[26] Bryantsev, V.S. and Faglioni, F. (2012) Predicting Autoxidation Stability of Ether- and Amide-Based Electrolyte Solvents for Li-Air Batteries. Journal of Physical Chemistry A, 116, 7128-7138. http://dx.doi.org/10.1021/jp301537w

[27] Laoire, C.O., Mukerjee, S. and Abraham, K.M. (2010) Influence of Nonaqueous Solvents on the Electrochemistry of Oxygen in the Rechargeable Lithium-Air Battery. Journal of Physical Chemistry C, 114, 9178-9186. http://dx.doi.org/10.1021/jp102019y

[28] Xu, D., Wang, Z., Xu, J., Zhang, L.L. and Zhang, X.B. (2012) Novel DMSO-Based Electrolyte for High Performance Rechargeable Li- $\mathrm{O}_{2}$ Batteries. Chemical Communications, 48, 6948-6950. http://dx.doi.org/10.1039/c2cc32844e

[29] Peng, Z., Freunberger, S.A., Chen, Y. and Bruce, P.G. (2012) A Reversible and Higher-Rate Li-O ${ }_{2}$ Battery. Science, 337, 563-566. http://dx.doi.org/10.1126/science.1223985

[30] Zhang, Z., Lu, J., Assary, R.S., Du, P., Wang, H.H., Sun, Y.K., et al. (2011) Increased Stability toward Oxygen Reduction Products for Lithium-Air Batteries with Oligoether-Functionalized Silane Electrolytes. Journal of Physical Chemistry C, 115, 25535-25542. http://dx.doi.org/10.1021/jp2087412

[31] Li, F.J., Zhang, T. and Zhou, H.S. (2013) Challenges of Non-Aqueous Li-O $\mathrm{O}_{2}$ Batteries: Electrolytes, Catalysts, and Anodes. Energy \& Environmental Science, 6, 1125-1141. http://dx.doi.org/10.1039/c3ee00053b

[32] Younesi, R., Hahlin, M., Bjorefors, F., Johansson, P. and Edstrom, K. (2012) Li-O ${ }_{2}$ Battery Degradation by Lithium Peroxide $\left(\mathrm{Li}_{2} \mathrm{O}_{2}\right)$ : A Model Study. Chemistry of Materials, 25, 77-84. http://dx.doi.org/10.1021/cm303226g

[33] Veith, G.M., Nanda, J., Delmau, L.H. and Dudney, N.J. (2012) Influence of Lithium Salts on the Discharge Chemistry of Li-Air Cells. Journal of Physical Chemistry Letters, 3, 1242-1247. http://dx.doi.org/10.1021/jz300430s

[34] Xu, W., Hu, J.Z., Engelhard, M.H., Towne, S.A., Hardy, J.S., Xiao, J., et al. (2012) The Stability of Organic Solvents and Carbon Electrode in Nonaqueous $\mathrm{Li}^{-} \mathrm{O}_{2}$ Batteries. Journal of Power Sources, 215, 240-247. http://dx.doi.org/10.1016/j.jpowsour.2012.05.021

[35] Suo, L., Hu, Y.S., Li, H., Armand, M. and Chen, L. (2013) A New Class of Solvent-in-Salt Electrolyte for HighEnergy Rechargeable Metallic Lithium Batteries. Nature Communications, 4, 1-9. http://dx.doi.org/10.1038/ncomms2513

[36] Wang, Z.L., Xu, D., Xu, J.J. and Zhang, X.B. (2014) Oxygen Electrocatalysts in Metal-Air Batteries: From Aqueous to Nonaqueous Electrolytes. Chemical Society Reviews, 43, 7746-7786. http://dx.doi.org/10.1039/C3CS60248F

[37] Xie, B., Lee, H.S., Li, H., Yang, X.Q., McBreen, J. and Chen, L.Q. (2008) New Electrolytes Using $\mathrm{Li}_{2} \mathrm{O}$ or $\mathrm{Li}_{2} \mathrm{O}_{2}$ Oxides and Tris(pentafluorophenyl) Borane as Boron Based Anion Receptor for Lithium Batteries. Electrochemistry Communications, 10, 1195-1197. http://dx.doi.org/10.1016/j.elecom.2008.05.043

[38] Wang, Y., Zheng, D., Yang, X.Q. and Qu, D.Y. (2011) High Rate Oxygen Reduction in Non-Aqueous Electrolyte with the Addition of Perfluorinated Additives. Energy \& Environmental Science, 4, 3697-3702.

[39] Zhang, S. and Read, J. (2011) Partially Fluorinated Solvent as a Co-Solvent for the Non-Aqueous Electrolyte of Li/Air Battery. Journal of Power Sources, 196, 2867-2870. http://dx.doi.org/10.1016/j.jpowsour.2010.11.021

[40] Mizuno, F., Nakanishi, S., Shirasawa, A., Takechi, K., Shiga, T., Nishikoori, H. and Iba, H. (2014) Design of NonAqueous Liquid Electrolytes for Rechargeable Li- $\mathrm{O}_{2}$ Batteries. Electrochemistry, 79, 876-881. 
http://dx.doi.org/10.5796/electrochemistry.79.876

[41] Herranz, J., Garsuch, A. and Gasteiger, H.A. (2012) Using Rotating Ring Disc Electrode Voltammetry to Quantify the Superoxide Radical Stability of Aprotic Li-Air Battery Electrolytes. Journal of Physical Chemistry C, 116, 19084-19094. http://dx.doi.org/10.1021/jp304277z

[42] Li, F.J., Kitaura, H. and Zhou, H.S. (2013) The Pursuit of Rechargeable Solid-State Li-Air Batteries. Energy \& Environmental Science, 6, 2302-2311. http://dx.doi.org/10.1039/c3ee40702k

[43] Croce, F., Appetecchi, G.B., Persi, L. and Scrosati, B. (1998) Nanocomposite Polymer Electrolytes for Lithium Batteries. Nature, 394, 456-458. http://dx.doi.org/10.1038/28818

[44] Kumar, J. and Kumar, B. (2009) Development of Membranes and a Study of Their Interfaces for Rechargeable Lithium-Air Battery. Journal of Power Sources, 194, 1113-1119. http://dx.doi.org/10.1016/j.jpowsour.2009.06.020 